American Journal of Pharmaceutical Education 2020; 84 (2) Article 7529.

\title{
RESEARCH
}

\section{Economic Contributions of a College of Pharmacy to the Surrounding Communities and State}

\author{
Marie Chisholm-Burns, PharmD, MPH, MBA, ${ }^{\mathrm{a}}$ Cyril F. Chang, PhD, ${ }^{\text {,c }}$ Shelia Cooper, $\mathrm{BS}^{\mathrm{a}}$ \\ ${ }^{a}$ University of Tennessee Health Science Center College of Pharmacy, Memphis, Tennessee \\ ${ }^{\mathrm{b}}$ Methodist Le Bonheur Center for Healthcare Economics, Memphis, Tennessee \\ ${ }^{c}$ University of Memphis Fogelman College of Business and Economics, Memphis, Tennessee \\ Submitted January 23, 2019; accepted July 22, 2019; published February 2020.
}

Objective. To quantify the monetary value of economic contributions of a state-funded college of pharmacy as it pursues its missions of teaching, research, service, and patient care.

Methods. An economic analysis was performed by applying the Impact Analysis for Planning (IMPLAN) Economic Input-Output Model to financial and enrollment data of the University of Tennessee Health Science Center College of Pharmacy.

Results. A total of $\$ 94.1$ million was attributed to the college in fiscal year 2018 , which included $\$ 50.7$ million of total direct expenditures by the college, its students, and visitors; the indirect effect of over $\$ 17$ million; and the induced effect of $\$ 26.4$ million. The college directly employed 117 full-time equivalent employees and 39 pharmacy residents, and supported 763 additional jobs through the economic activities it stimulated. In addition, the presence of the college and its economic contribution enabled federal, state, and local taxing authorities to collect $\$ 12$ million in tax revenues to support government and public programs.

Conclusion. Demonstrating the economic value of colleges of pharmacy is critical when seeking support from campus administrators, state legislators, charitable foundations, government agencies, and industry.

Keywords: economic contribution, economic impact analysis, college of pharmacy

\section{INTRODUCTION}

Like other professional institutions of higher learning in the health sciences, schools and colleges of pharmacy aim to improve the health of people in surrounding communities, as well as throughout the state, nation, and world. They strive to do so through training future pharmacists and scientists, leading therapeutic-related research and providing services that include delivery of pharmaceutical care. The organizational structure of pharmacy schools can vary as they may be integrated as part of a comprehensive university structure, organized as a free-standing institution, or part of a health science center campus that trains pharmacists and other healthcare professionals, such as physicians, nurses, and dentists. Additionally, colleges of pharmacy play a key role in improving the quality of health care by developing and studying therapeutics and more effective ways to deliver care.

Corresponding Author: Marie Chisholm-Burns, University of Tennessee Health Science Center College of Pharmacy, 881 Madison Ave., Ste. 264, Memphis, TN 38163. Tel: 901-4486036. Email: mchisho3@uthsc.edu
Colleges of pharmacy, as well as other health professions colleges, make another significant, but little noticed and less understood, contribution. They are part of the economic engine that drives state and local economies, and contribute to the economic health of the communities they serve. ${ }^{1,2}$ Previous reports have, for example, attempted to capture the economic contributions of schools and colleges of medicine. ${ }^{3-5}$ In March 2018, the American Association of Medical Colleges published a report which noted that US medical schools contributed $\$ 182$ billion to the gross domestic product in 2015, paying approximately $\$ 119$ billion in annual wages, salaries, and benefits, and generating 2.3 million jobs. ${ }^{3}$ In a more specific example, a report from the School of Medicine at the University of Nevada, noted that the school's total economic contribution (including employment, payroll and benefits, operations, and expenditures related to the school's education and research enterprise and practice plans) to the state of Nevada in 2015 was $\$ 292.8$ million. $^{4}$ In 2007, Wright State University's Boonshoft School of Medicine contributed $\$ 850.5$ million to the state of Ohio's economy and supported more than 13,000 jobs. ${ }^{5}$ This analysis included 


\section{American Journal of Pharmaceutical Education 2020; 84 (2) Article 7529.}

the school's education and research enterprise, physician group, and "resident training and research enterprise of core affiliated hospitals."

A PubMed search found that published studies examining the economic impact of pharmacy schools on their state and local economies are scarce. We believe the lack of research in this area has resulted in a lack of understanding and appreciation of schools of pharmacy as economic drivers. This is not surprising as schools of pharmacy usually present themselves to the external community simply as institutions of higher learning in the health care field. Their relationship with and contributions to the larger external economy of which they are a part is not common knowledge among most people, including academics and health care professionals.

The purpose of this study was to address this knowledge gap by reporting the economic contributions of colleges of pharmacy, using the University of Tennessee Health Science Center College of Pharmacy (UTHSC COP) as an example. The larger aim was to broaden the perception of pharmacy schools as a source of economic stimulation that generates positive economic returns for the public and private dollars invested in these institutions. Specifically, this manuscript illustrates how a college of pharmacy generates economic contributions, and summarizes the economic contributions of Tennessee's flagship college of pharmacy to the state's economies and communities that benefit from its educational, research, and patient care activities.

The UTHSC COP was one of the first pharmacy schools in the United States to grant the Doctor of Pharmacy (PharmD) degree (since 1969) and one of the first to adopt the PharmD as the entry-level degree (since 1984). Graduates of the college consistently achieve first-time pass rates on the North American Pharmacist Licensure Examination (NAPLEX) of greater than $95 \%$, which exceeds national and state averages. The college has a statewide imprint, with campuses in all three major cities in Tennessee, which represent the three major regions of the state: West Tennessee (Memphis), Middle Tennessee (Nashville), and East Tennessee (Knoxville). All students attend the Memphis campus for a minimum of eight months in the first year (P1) of the PharmD curriculum. Following the P1 year, students reside on the Memphis, Nashville, or Knoxville campuses. Thus, the college has tremendous student presence statewide, with 488 student pharmacists in Memphis, 121 in Knoxville, and 93 in Nashville (total of 702) during the 2017-2018 academic year. Additionally, students spend their last one and a half years of the PharmD program at advanced pharmacy practice experience (APPE) sites that span the entire state, outside the state, and globally through the college's international study program. ${ }^{6}$ Through APPEs from July 1 , 2017, through June 30, 2018, the college had: over 420 affiliate or preceptor faculty members providing care and training to our students in various pharmacy facilities throughout Tennessee; approximately 125 affiliate agreements which include mostly pharmacies and hospitals in Tennessee, 10 affiliate agreements with sites out-of-state, and 12 affiliate agreements with international sites; greater than 12 experiential exchange programs in 10 different countries; and 39 residency program affiliations statewide. In summary, the UTHSC COP serves the health care needs of Tennessee and beyond, and was believed to provide a strong economic influence. In this study, we attempted to assess the monetary value of the college's economic contributions as it pursues its missions of teaching, research, service, and patient care.

\section{METHODS}

The term "economic contribution" is defined in this study as the economic benefits of an existing economic entity, either for-profit, nonprofit, or government owned, on the level of economic activity in a regional or local economy. It measures the change in economic activities, such as business transactions and employment, that results from the presence of the entity in question. These economic changes are important because they signal enhancement in economic well-being, thereby accomplishing the principal aim of state and local economic development efforts.

This study used expenditure and enrollment data from various administrative sources to estimate the statewide economic contributions of UTHSC COP, its students, and the employees who spend their earned wages and salaries in local markets. Specifically, revenues and expenditure data were provided by the UTHSC Office of Finance, while student expenditures were estimated based on official estimates of student expenses. ${ }^{7}$ Some of the budget dollars were identified as one-time appropriations or carryover funds from a previous fiscal year and excluded from the analysis so as to not inflate the contribution estimates. These data were supplemented by relevant, publicly available data, such as Consumer Price Index (CPI) data from the US Department of Labor, ${ }^{8}$ and federal General Services Administration (GSA) travel reimbursement rates. ${ }^{9}$ For this study, all data collected were for fiscal year (FY) 2018, which started July 1, 2017, and ended June 30, 2018.

The economic contribution of the college was estimated using the Economic Impact Analysis for Planning software system, IMPLAN Pro, Version 3.1 (IMPLAN Group LLC, Huntersville, NC), which was developed 


\section{American Journal of Pharmaceutical Education 2020; 84 (2) Article 7529.}

originally by the US Department of Interior and currently maintained by the Minnesota IMPLAN Group (MIG). The IMPLAN software system is the most commonly used analytical tool for analyzing the economic contribution of existing institutions and has been used by more than 500 universities, government agencies, and nonprofit organizations to estimate the economic and fiscal impacts of fresh investments and/or changes in economic activities. ${ }^{10}$

Conceptually, as shown in Figure 1, the IMPLAN model is essentially a mathematical representation of a regional, state, or local economy. ${ }^{11,12}$ It is a regional input-output ( $\mathrm{I} / \mathrm{O})$ model designed under a set of specific assumptions to capture analytically all the business transactions involving the industries and consumers located and residing in a region or a state for a specific period of time, such as a year. ${ }^{11}$ Thus, in this study, the IMPLAN I/O model was used to capture the economic benefits of all the business transactions involving UTHSC COP and its students and visitors on the economy of Tennessee for FY 2018. The underlying model was static (ie, the economic contribution generated is assumed to have no effect on input prices and hence has no influence on input substitution of, for example, labor for capital) and assumed that the industrial technology implied by the national economy remained constant during the study period and was applicable to the economy of the state of Tennessee. ${ }^{12}$ Further, the IMPLAN model assumed that total revenues equaled total expenditures. ${ }^{11}$ This assumption thus allowed the use of budgeted revenues to represent actual expenditures when the actual outlays were unavailable. To regionalize the input-output relationships that describe the trade flows between the region and the rest of the country, the IMPLAN software developed for a particular state uses a set of proprietary Regional Purchase Coefficients estimated econometrically for each of the major economic sectors (health care, education, banking, etc.) of the state to measure the relative proportions of goods and services purchased locally versus from other states.
The IMPLAN I/O model begins with a direct effect, which was represented in this study by the sum of: total operating and capital expenditures of UTHSC COP for FY 2018; total spending by its students on food, housing, and other daily needs; and total dollars spent by visitors when they visited UTHSC COP campuses during FY 2018. Direct effects were thus the initial dollars spent by UTHSC COP and its students in the local community and beyond. This was the "input" that drove the total or overall economic contribution of the college. It was a contribution to the local economy in the sense that the community and beyond would be poorer economically in the absence of the college.

The funds flowing from the three major types of purchases comprising the direct effect do not stop once the initial transactions are made. The purchases set off additional rounds of buying by the contractors, vendors, merchants, etc., who received the money, which in turn sets off additional rounds of selling, as dollars change hands repeatedly to stimulate further economic activities. These additional business transactions are referred to as the multiplier or ripple effect of the original direct effect. For example, a multiplier of 1.75 implies that for every dollar spent initially, an additional $\$ 0.75$ of economic activity is generated, for a total of $\$ 1.75$ of overall stimulation. Though varying from industry to industry, the IMPLAN multipliers are typically in the range of 1-2 at the local level and 2-3 at the state level. ${ }^{13}$ The IMPLAN model used for this report was procured from MIG and was designed and calibrated specifically for Tennessee and its 95 counties. Finally, the total multiplier effect comprises two additional subcategories of downstream effects: the indirect effect and the induced effect. ${ }^{11}$ Indirect effects were the changes in inter-industry transactions when supplying industries (eg, retail establishments, restaurants, landlords, real estate firms) respond to increased demands from the directly affected industries and markets (eg, the hospital inpatient care market). Induced effects reflected changes in local spending that resulted from increases in business and individual incomes in the

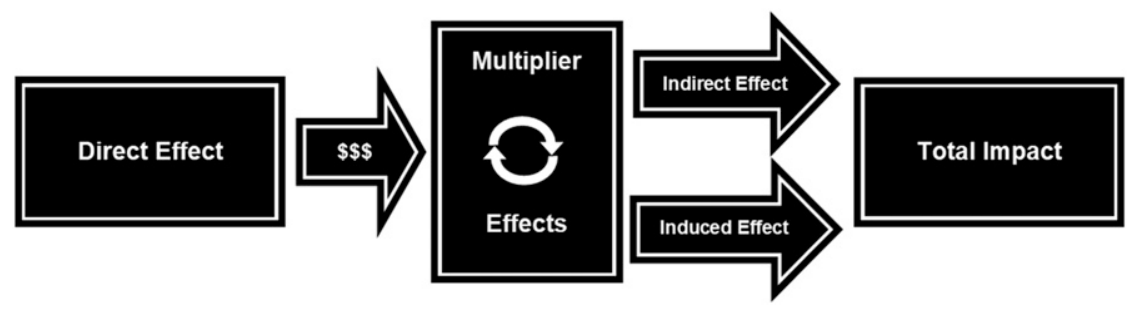

Figure 1. A Conceptual Overview of the Input/Output Model Used to Determine the Economic Impact of the University of Tennessee Health Science Center College of Pharmacy. Direct effect includes the spending by the college and its students, employee salaries, wages, and college's direct purchases of goods and services in local markets. Multiplier effects refer to dollars that change hands multiple times, and the total impact is comprised of the direct effect, the indirect effect, and the induced effect. 


\section{American Journal of Pharmaceutical Education 2020; 84 (2) Article 7529.}

industries affected by the direct and indirect effects of the college.

The total economic contribution of the college and its three effects needed to be defined and measured, and in this study were represented by the total output of goods and services produced that could be attributed to the existence of the college. Defined as the monetary value of total goods and services produced in Tennessee in a given year, total output is the most inclusive representation of aggregate economic activities of a regional, state or local economy.

In addition to the estimated dollar values of the total output of the college and its three major components, the IMPLAN model was used to describe the contributions (ie, the total output) of the college in three areas. In the first area, federal, state, and local taxing, authorities collect taxes when business transactions take place. The direct, indirect, and induced effects discussed above represent business transactions that stimulate the economy and provide employers with the necessary revenues to pay employees. They also represent opportunities for governments to collect taxes to support various public programs such as public safety, health care, and education. The second area is the jobs created in the local economy because of the presence of the college and its students. They include both the jobs created by the direct effect of the college and the additional jobs in the community supported by the subsequent multiplier effects of upstream and downstream benefits of the college's initial economic stimulation. The third area is the affected industries. These are the top ten downstream industries that are most affected economically either positively or negatively by the existence of the college.

Finally, the IMPLAN software provides the flexibility of estimating the economic contribution of a college of pharmacy to: the economy of the county where the campus is located; the larger regional economy which includes the economy of both the home county and the surrounding counties; or the economies of all counties in the state. When applying the IMPLAN methodology, we estimated the contributions of the college's three campuses (located in the eastern, central and western parts of the state) to the entire state, which reflects the geographic focus on the state economy. This provided the fullest IMPLAN estimates possible so that the benefits received by all counties in Tennessee would be included in the results, with the three urban counties where campuses were located getting most of the benefits, and other counties, especially those in rural areas, getting increasingly fewer benefits as the impact relationship gets weaker with distance from each of the campuses.

\section{RESULTS}

The UTHSC COP's total budget is a major source of college revenues that enables the college to pay salaries and wages and to purchase goods and services that subsequently give rise to the college's direct economic contribution to the county and state. In FY 2018, the college's budgeted revenues totaled $\$ 35.8$ million. Of this, the largest share of $\$ 15.9$ million (or $44.5 \%$ of total) came from student tuition and fees, followed by $\$ 8.2$ million from research grants and contracts (23\% of total), and $\$ 6.7$ million from state appropriations (18.6\% of total). The Memphis campus received $91.4 \%$ of the total budgeted revenues, with the remainder going to the Knoxville $(4.9 \%)$ and Nashville (3.7\%) campuses.

Total expenditures from FY 2018 were approximately $\$ 50.7$ million, with the largest share of total college spending associated with operating and capital expenditures for maintaining the college and for carrying out research activities. Additional sources of the college's total expenditures were the purchases made by pharmacy students pursuing their PharmD degrees and money spent by visitors who visited one of the college's campuses in FY 2018. In brief, the college's operating, capital, and research expenditures represented $65.6 \%$ (or $\$ 33.3$ million) of total college expenditures, which according to the IMPLAN I/O Model, constituted the college's total direct economic contribution or benefits. The rest of the total direct economic contribution was made by pharmacy students (33\% of the total or $\$ 16.7$ million) and visitors $(1.4 \%$ or $\$ 726,432)$. At the three locations where the college's students and research activities were concentrated, the Memphis campus contributed \$42.6 million $(84 \%)$ of the total direct benefits. The Knoxville and Nashville campuses contributed $\$ 4.6$ million (9\%) and $\$ 3.5$ million (7\%), respectively, of the total direct benefits in FY 2018.

The major findings of the total economic contribution of the college for FY 2018 are presented in Table 1. Specifically, the college and its students and visitors contributed over $\$ 94.1$ million to the Tennessee economy in FY 2018. This total contribution is represented by the current dollar value of total economic output generated for the economy of Tennessee, and includes not only the direct contribution of the college, but also the indirect and induced effects that together represent the multiplier effects of additional economic contributions. Also reported in Table 1 are tax revenues and community jobs supported by expenditures of the college, its students, and visitors. The college and its students and visitors supported 763 community jobs in Tennessee (641 jobs were created in the Memphis area, 69 in the Knoxville area, and 53 in the 


\section{American Journal of Pharmaceutical Education 2020; 84 (2) Article 7529.}

Nashville area); these community jobs are in addition to the 117 full-time equivalent (FTE) faculty and staff jobs and 39 pharmacy residents employed or supported directly by the college's campuses in Memphis, Knoxville, and Nashville. In addition, the college along with its students and visitors contributed approximately $\$ 12$ million of federal, state, and local tax revenues that enabled governments to finance public programs and services throughout the state for the benefit of Tennessee residents.

In terms of the relative contributions of the three campuses to the state economy, the total economic contribution of the college for FY 2018 was concentrated predominantly ( $84 \%$ of state total contribution) in the Memphis area, where the college's parent campus is located. The other two campuses contributed 9\% (Knoxville) and 7\% (Nashville) in FY 2018. The college created roughly $\$ 79$ million of total economic benefits in the Memphis area, \$8.5 million in Knoxville, and \$6.6 million in Nashville, totaling approximately $\$ 94.1$ million.

The three separate layers of economic effect (direct effect, indirect effect, and induced effect) and their breakdowns according to the three major sources of original direct effect (the college, students, and visitors) are presented in Table 2. The direct effect of the college's economic contribution as measured by the total economic output stimulated by the combined expenditures of the college and its students and visitors was estimated to be $\$ 50.7$ million (or $53.9 \%$ of total output) for Tennessee in FY 2018. The indirect effect and induced effect were estimated to be approximately $\$ 17$ million (18\% of total) and $\$ 26.4$ million $(28.1 \%$ of total), respectively.

As a public institution of higher education, UTHSC is exempted from federal income and excise taxes, as well as local sales and property taxes. However, its employees and students are not exempt from paying individual income taxes or state and local taxes, such as sales tax and property tax. In addition to these taxes paid directly by the college's students and employees, the indirect and induced effects of the college's economic contribution generate additional federal, state, and local tax revenues from the affected industries and businesses. Estimates of total federal, state, and local tax revenues that could be attributed to the presence of the college's campuses in Memphis, Knoxville, and Nashville are presented in Table 3.

In terms of federal taxes, the college, its students, and visitors made it possible for federal taxing authorities to collect approximately $\$ 8.5$ million (or $70.8 \%$ of total taxes) in federal taxes, such as federal corporate income taxes and federal payroll taxes for social security

Table 1. Total Economic Contribution of University of Tennessee Health Science Center College of Pharmacy, FY 2018

\begin{tabular}{|c|c|c|c|c|}
\hline & \multicolumn{3}{|c|}{ Sources of Economic Contribution $^{\text {a }}$} & \multirow[b]{2}{*}{ Total } \\
\hline & College & Students & Visitors & \\
\hline $\begin{array}{l}\text { Economic output generated for Tennessee, } \$ \\
\% \text { of total }\end{array}$ & $\begin{array}{c}61,723,478 \\
65.6\end{array}$ & $\begin{array}{l}31,030,550 \\
33.0\end{array}$ & $\begin{array}{l}1,348,049 \\
1.4\end{array}$ & $\begin{array}{c}94,102,076 \\
100.0\end{array}$ \\
\hline Federal, state, and local tax revenues, $\$$ & $7,844,130$ & $3,943,518$ & 171,317 & $11,958,965$ \\
\hline$\%$ of total & 65.6 & 33.0 & 1.4 & 100.0 \\
\hline Jobs created, No. & 501 & 252 & 11 & 763 \\
\hline
\end{tabular}

${ }^{a}$ Numbers and percentages may not sum because of rounding

Table 2. Estimates of Total Economic Output Generated for Tennessee by the University of Tennessee Health Science Center College of Pharmacy, FY 2018

\begin{tabular}{|c|c|c|c|c|}
\hline & \multicolumn{3}{|c|}{ Sources of Economic Contribution ${ }^{\text {a }}$} & \multirow[b]{2}{*}{ UTHSC COP } \\
\hline & College & Students & Visitors & \\
\hline Direct effect, $\$$ & $33,261,344$ & $16,721,640$ & 726,432 & $50,709,416$ \\
\hline Indirect Effect, \$ & $11,135,657$ & $5,598,284$ & 243,204 & $16,977,145$ \\
\hline$\%$ of total contribution & 18.0 & 18.0 & 18.0 & 18.0 \\
\hline Induced Effect, \$ & $17,326,478$ & $8,710,626$ & 378,412 & $26,415,516$ \\
\hline Total impact, $\$$ & $61,723,478$ & $31,030,550$ & $1,348,049$ & $94,102,076$ \\
\hline$\%$ of total contribution & 100.0 & 100.0 & 100.0 & 100.0 \\
\hline
\end{tabular}

${ }^{a}$ Numbers and percentages may not sum due to rounding 


\section{American Journal of Pharmaceutical Education 2020; 84 (2) Article 7529.}

and Medicare in FY 2018. State and local taxing authorities collected another $\$ 3.5$ million (or $29.2 \%$ of total) of tax revenues (eg, sales and excise taxes and local property taxes) to support the operations of state and local governments and their various public service programs (Table 3 ). Taxing authorities collected the largest share of total tax revenues (approximately $\$ 10$ million or $83.1 \%$ of total federal, state, and local taxes) in the Memphis area, followed by $\$ 1.1$ million ( $9.5 \%$ of total) in Knoxville and $\$ 0.9$ million ( $7.4 \%$ of total) in Nashville.

Another way to examine the tax contributions of the college is to examine the sources (ie, tax bases) of federal, state, and local taxes collected because of the presence of the college, its students, and visitors. Federal, state, and local tax revenues according to these major tax base sources are presented in Table 4. The two largest sources, employee compensation and individual households, accounted for approximately $81.9 \%$ of total federal taxes collected in FY 2018. At the state and local levels, the single largest source of state and local taxes was production and imports, accounting for $86.6 \%$ of total state and local taxes collected in FY 2018.

The top 10 most affected businesses and industries, in terms of total output produced, are reported in Table 5. The industry sectors that benefited the most from the presence of the college included such major industries as other institutions of higher education, real estate owners and firms, hospitals, physician offices, full-service and limited-service restaurants, wholesale trade establishments, and local government enterprises. The distribution of the economic contribution of the college was uneven among the various industries, with the top 10 affected industries receiving $68.6 \%$ of the total economic contribution.

\section{DISCUSSION}

As a state-supported college in a large health science center, the college received about $\$ 6.7$ million of annual funding support from the state government in FY 2018. However, our study found that for every dollar appropriated for the college, the benefit to the state, in terms of total output (goods and services) produced for Tennessee that could be attributed to the presence of the college, was approximately $\$ 14$. The ratio rose to $16: 1$ when the federal, state, and local tax revenues stimulated by the college were added. These data have therefore been used to educate stakeholders, including those who are in control of resources, about the economic contributions of the college. It is the first step in the process of demonstrating impact to others in order to garnish needed future resources for the college.

In Tennessee, and elsewhere across the country, taxpayers increasingly want to know whether their tax dollars have been put to good use. A formal benefit-cost analysis of alternative uses of state dollars and their implied opportunity costs is beyond the scope of this economic contribution study. However, the benefit-tocost ratios reported for a single institution here and the substantial non-state resources shown suggest that nonstate revenue sources such as tuition and fees and research grants and contracts far exceed state-provided funding. These positive rates of return also strengthen

Table 3. Impact of the University of Tennessee Health Science Center College of Pharmacy on Federal, State, and Local Tax Revenues for FY 2018

\begin{tabular}{|c|c|c|c|c|}
\hline & Memphis & Knoxville & Nashville & UTHSC COP \\
\hline Federal tax revenues $(\$)$ & $7,037,516$ & 804,631 & 622,832 & $8,464,979$ \\
\hline$\%$ of total tax revenues & 70.8 & 70.8 & 70.8 & 70.8 \\
\hline$\%$ of total tax revenues & 29.2 & 29.2 & 29.2 & 29.2 \\
\hline Total tax revenues $(\$)$ & $9,942,306$ & $1,136,749$ & 879,910 & $11,958,965$ \\
\hline$\%$ of total tax revenues by location & 100.0 & 100.0 & 100.0 & 100.0 \\
\hline
\end{tabular}

Note: Numbers and percentages may not sum due to rounding

Table 4. Total Economic Contribution of University of Tennessee Health Science Center College of Pharmacy: Estimates of Federal, State, and Local Taxes by Source of Tax Base, FY2018

\begin{tabular}{|c|c|c|c|c|c|c|}
\hline Source & Federal Taxes & $(\%)$ & State and Local Taxes & $(\%)$ & Total Taxes & $(\%)$ \\
\hline Employee compensation (\$) & $4,230,355$ & 50.0 & 45,659 & 1.3 & $4,276,014$ & 35.8 \\
\hline Proprietor income $(\$)$ & 149,883 & 1.8 & & & 149,883 & 1.3 \\
\hline Households (\$) & $2,697,160$ & 31.9 & 215,805 & 6.2 & $2,912,965$ & 24.4 \\
\hline Corporations (\$) & 963,668 & 11.4 & 207,261 & 5.9 & $1,170,929$ & 9.8 \\
\hline All sources $(\$)$ & $8,464,979$ & 100.0 & $3,493,986$ & 100.0 & $11,958,965$ & 100.0 \\
\hline
\end{tabular}

Note: Numbers and percentages may not sum due to rounding 


\section{American Journal of Pharmaceutical Education 2020; 84 (2) Article 7529.}

Table 5. Top 10 Industries Affected by University of Tennessee Health Science Center (UTHSC) College of Pharmacy's Economic Contribution, FY 2018

\begin{tabular}{lr}
\hline Affected Industries & \multicolumn{1}{c}{$\begin{array}{c}\text { Total } \\
\text { Output }(\mathbf{\$})\end{array}$} \\
\hline 1. Junior colleges, colleges, universities, & $50,964,066$ \\
$\quad$ and professional schools & \\
2. Real estate & $6,648,900$ \\
3. Full-service restaurants & 799,533 \\
4. Limited-service restaurants & $1,005,292$ \\
5. Hospitals & $1,667,472$ \\
6. Employment services & 526,661 \\
7. Other educational services & 311,087 \\
8. Services to buildings & 341,975 \\
9. Wholesale trade & $1,819,428$ \\
10. Retail-general merchandise stores & 465,796 \\
\hline Top 10 total (\$) & $64,530,210$ \\
Total contribution of UTHSC & $94,102,076$ \\
$\quad$ College of Pharmacy (\$) & \\
Top 10 as $\%$ of total $(\%)$ & 68.6 \\
\hline
\end{tabular}

college and university officials' case for wise use of state resources at a time of fiscal restraint and budgetary difficulties. Moreover, the contribution estimates reported here are likely to be conservative as we did not include the onetime, nonrecurring revenues generated by the UTHSC COP, such as single purchases. If these onetime revenues were included in the estimation, the total economic contribution of the college would have been $15.1 \%$ greater than the amount reported in this study, raising the total economic output of the college from $\$ 94.1$ million to an estimated $\$ 108.3$ million.

The total economic output of $\$ 94.1$ million by UTHSC COP, although considerably less than the economic contributions of medical schools such as those at the University of Nevada and Wright State University, is noteworthy nonetheless, particularly as the college does not have the level of revenue-generating enterprise that medical schools have. ${ }^{4,5}$ Medical schools, on the other hand, often have practice plans, physician groups, and/or affiliated hospitals that may be incorporated into analyses of their economic contributions. The economic contributions of UTHSC COP are not only deep, but also wide. For example, the presence of the college provided jobs throughout the local economy many times more than the ones employed directly by the college in the three major cities in Tennessee and beyond. In addition, the multiplier effects that expanded the initial college spending created wavelike downstream benefits for other industries, such as retail establishments, restaurants, real estate firms, and hospitals and clinics.
Each year the college graduates pharmacy students who either join the healthcare workforce as professional pharmacists or continue their training to become health system or research specialists. The healthcare, higher education, and business contributions of these graduates are real and likely to be substantial over the course of their careers, but are not always measured in monetary terms. Similarly, the research contributions of faculty members and graduate students in terms of new knowledge gained and potential lives saved are significant but also beyond the scope of this study. An additional limitation of this work is that, as an economic contribution study, it did not consider the opportunity costs of the revenues that fund the operation of the college. Revenues, whether public or private, could have been used in alternative ways, and using these funds differently might have resulted in an even greater economic impact. This and other similar questions are beyond the scope of this study. Another limitation is that the multipliers used in most inputoutput studies are customarily estimated under the "business as usual" assumption. ${ }^{14}$ Hence, the resulting contribution estimates do not account for sudden and unexpected changes in the national economy that may damage state and local economies. Despite these limitations, this case study adds to the economic impact and contribution literature by providing a welldefined financial contribution summary of a public college of pharmacy and can serve as a model for other colleges of pharmacy, public or private, interested in knowing the economic impacts of new investments or contributions from existing programs.

\section{CONCLUSION}

Health professions educational programs such as colleges of pharmacy and medicine make substantial contributions to local and state economies across the United States. Likewise, the results presented herein provide evidence demonstrating that the UTHSC COP is a significant component of the economy of Tennessee and that of several of its major cities and communities. This study, and similar economic impact studies conducted by other colleges of pharmacy and various health professions, regardless of sources of funding (ie, state vs non-state), may be used to support advocacy efforts for resources and program growth. Such studies may also be used to increase public awareness of the value of higher education beyond the direct benefits to the students/graduates and employees of those institutions.

\section{ACKNOWLEDGMENTS}

The authors would like to thank Drs. Jenny Johnson and Christina Spivey for assistance in manuscript 


\section{American Journal of Pharmaceutical Education 2020; 84 (2) Article 7529.}

preparation. Marie Chisholm-Burns serves on the board of directors for the Accreditation Council for Pharmacy Education (ACPE). This manuscript does not represent ACPE or the board's opinions or views.

\section{REFERENCES}

1. Gourley D, White-Means S, Wallace J. The economic impact of a college of pharmacy. Am J Pharm Educ. 2008;72(1):Article 1. 2. Friesner D, Rosenman R, Bozman CS. Economic impact of pharmacy graduates on a regional economy. Am J Pharm Educ. 2009;73(3):Article 46.

3. Association of American Medical Colleges. Economic impact of AAMC medical schools and teaching hospitals. March 2018. https:// www.aamc.org/download/488250/data/executive-summary.pdf. Accessed February 20, 2020.

4. McMillin A. Report documents School of Medicine's contributions to Nevada's economy. May 17, 2016. https:// med.unr.edu/news/archive/2016/economic-impact. Accessed February 20, 2020.

5. Wright State University. The economic impact of the Wright State University Boonshoft School of Medicine. 2008 executive report. https://medicine.wright.edu/sites/medicine.wright.edu/files/uploads/0/ article/economics.pdf. Accessed February 20, 2020.

6. Gourley DR, Vaidya VA, Hufstader MA, Ray MD, ChisholmBurns MA. An international capstone experience for pharmacy students. Am J Pharm Educ. 2013;77(3): Article 50.
7. University of Tennessee Health Science Center. 2018-19 college of pharmacy estimated cost of attendance. https://www.uthsc.edu/ financial-aid/cost-of-attendance/documents/pharmacy-coa.pdf. Accessed February 20, 2020.

8. United States Department of Labor Bureau of Labor Statistics. CPI inflation calculator. https://www.bls.gov/data/ inflation_calculator.htm/. Accessed February 20, 2020.

9. General Services Administration. FY 2018 per diem rates for Tennessee. https://www.gsa.gov/travel/plan-book/per-diem-rates/ per-diem-rates-lookup/?action $=$ perdiems_report\&state $=$

TN\&fiscal_year $=2018 \&$ zip $=$ \&city. Accessed February 20, 2020. 10. Meter K, Goldenberg MP. Critical analysis of economic impact methodologies. In Exploring Economic and Health Impacts of Local Food Procurement. 2015. http://crossroads.igc.org/econimpacts.pdf. Accessed February 20, 2020.

11. University of Wisconsin Center for Cooperatives. IMPLAN methodology. http://reic.uwcc.wisc.edu/implan/. Accessed February 20, 2020.

12. IMPLAN Group LLC. Key assumptions of IMPLAN and input/ output analysis. https://implanhelp.zendesk.com/hc/en-us/articles/ 115009505587-Key-Assumptions-of-IMPLAN-Input-OutputAnalysis. Accessed February 20, 2020.

13. IMPLAN Group LLC. General information about multipliers. https://implanhelp.zendesk.com/hc/en-us/articles/115009505707. Accessed February 20, 2020.

14. Boardman AE, Greenberg DH, Vining AR, Weimer DL. CostBenefit Analysis: Concepts and Practice. $3^{\text {rd }}$ edition. Upper Saddle River, NJ: Prentice Hall; 2005. 